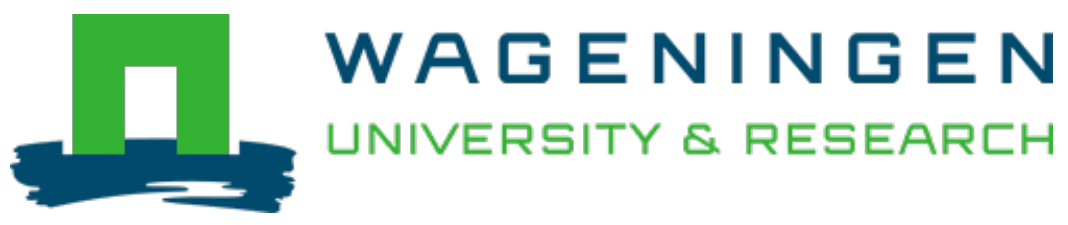

\title{
Effects of landscape structure on genetic diversity of Geum urbanum L. populations in agricultural landscapes
}

Flora

Schmidt, T.; Arens, P.F.P.; Smulders, M.J.M.; Billeter, R.; Liira, J. et al

https://doi.org/10.1016/j.flora.2008.07.005

This article is made publicly available in the institutional repository of Wageningen University and Research, under the terms of article $25 \mathrm{fa}$ of the Dutch Copyright Act, also known as the Amendment Taverne. This has been done with explicit consent by the author.

Article 25 fa states that the author of a short scientific work funded either wholly or partially by Dutch public funds is entitled to make that work publicly available for no consideration following a reasonable period of time after the work was first published, provided that clear reference is made to the source of the first publication of the work.

This publication is distributed under The Association of Universities in the Netherlands (VSNU) 'Article $25 \mathrm{fa}$ implementation' project. In this project research outputs of researchers employed by Dutch Universities that comply with the legal requirements of Article $25 \mathrm{fa}$ of the Dutch Copyright Act are distributed online and free of cost or other barriers in institutional repositories. Research outputs are distributed six months after their first online publication in the original published version and with proper attribution to the source of the original publication.

You are permitted to download and use the publication for personal purposes. All rights remain with the author(s) and / or copyright owner(s) of this work. Any use of the publication or parts of it other than authorised under article $25 \mathrm{fa}$ of the Dutch Copyright act is prohibited. Wageningen University \& Research and the author(s) of this publication shall not be held responsible or liable for any damages resulting from your (re)use of this publication.

For questions regarding the public availability of this article please contact openscience.library@,wur.nl 


\title{
Effects of landscape structure on genetic diversity of Geum urbanum L. populations in agricultural landscapes
}

\author{
Torsten Schmidt ${ }^{\mathrm{a}}$, Paul Arens ${ }^{\mathrm{b}}$, Marinus J.M. Smulders ${ }^{\mathrm{b}}$, Regula Billeter ${ }^{\mathrm{c}}$, Jaan Liira ${ }^{\mathrm{d}}$, \\ Isabell Augenstein ${ }^{\mathrm{e}}$, Walter Durka ${ }^{\mathrm{a}, *}$ \\ ${ }^{a}$ Helmholtz Centre for Environmental Research - UFZ, Department of Community Ecology, Theodor-Lieser Straße 4, \\ D-06120 Halle, Germany \\ ${ }^{\mathrm{b}}$ Plant Research International, Wageningen UR, P.O. Box 16, NL-6700 AA Wageningen, The Netherlands \\ ${ }^{\mathrm{c}}$ Swiss Federal Institute of Technology, Institute of Integrative Biology, Universitätsstraße 22, 8092 Zürich, Switzerland \\ ${ }^{\mathrm{d}}$ University of Tartu, Institute of Botany and Ecology, 40 Lai Street, 51005 Tartu, Estonia \\ ${ }^{\mathrm{e}}$ Helmholtz Centre for Environmental Research - UFZ, Department of Landscape Ecology, Permoser Straße 15, \\ D-04318 Leipzig, Germany
}

Received 29 September 2007; received in revised form 10 July 2008; accepted 15 July 2008

\begin{abstract}
Plant species in fragmented populations are affected by landscape structure because persistence within and migration among inhabited patches may be influenced by the identity and configuration of surrounding habitat elements. This may also be true for species of the semi-natural vegetation in agricultural landscapes. To determine the effect of landscape elements we analyzed Wood Avens (Geum urbanum L.) populations within three $4 \times 4 \mathrm{~km}^{2}$ agricultural landscapes in Germany, Switzerland and Estonia, which differ in levels of land use intensity and habitat fragmentation. Genetic variation was determined in 15 randomly selected populations in each landscape using 10 microsatellite loci. The landscape structure was assessed at two circles around each population, with radii defined by the range limits of spatial genetic autocorrelation. Multiple regression analysis was used to determine the influence of landscape structure variables for inter- and intrapopulation genetic diversity. Gene diversity was equally high in Germany $\left(H_{\mathrm{e}}=0.27\right)$ and Switzerland $\left(H_{\mathrm{e}}=0.26\right)$ but lower in Estonia $\left(H_{\mathrm{e}}=0.16\right)$. A high overall inbreeding coefficient $\left(F_{\mathrm{IS}}=0.89\right)$ was found, as expected for a selfing breeding system in $G$. urbanum. Genetic differentiation among populations was high (overall $F_{\mathrm{ST}}=0.43,0.48$, and 0.45 in Estonia, Switzerland and Germany, respectively), and did not differ among the three landscapes. Only a moderate influence of individual land use types on genetic diversity within and among populations was found with some idiosyncratic relationships. Genetic variation within populations was correlated to the amount of hedgerows positively in Estonia but negatively in Switzerland. The study demonstrates that the distribution of individual land use types affects the genetic pattern of a common plant species. However, different variables were identified to influence the genetic structure in three different landscapes.
\end{abstract}

\footnotetext{
*Corresponding author. Tel.: + 493455585314 ; fax: + 493455585329.

E-mail addresses: torsten.schmidt@ufz.de (T. Schmidt), paul.arens@wur.nl (P. Arens), rene.smulders@wur.nl (M.J.M. Smulders), regula.billeter@env.ethz.ch (R. Billeter), jaan.liira@ut.ee (J. Liira), isabell.augenstein@ufz.de (I. Augenstein), walter.durka@ufz.de (W. Durka).
} 
This indicates a major influence of landscape-specific land use history and stochastic processes determining gene flow and plant population structure.

(C) 2008 Elsevier GmbH. All rights reserved.

Keywords: Habitat fragmentation; Geum urbanum; Gene flow; Landscape genetics; Microsatellites; Population genetic structure

\section{Introduction}

Agricultural landscapes in which agricultural fields and semi-natural habitats co-occur cover more than half of the European surface area. This has forced many species to interact with agricultural systems and to depend on semi-natural habitats (Pimentel et al., 1992). Species diversity in cultural landscapes thus partially depends on the habitat heterogeneity maintained by land use (Maurer et al., 2006). However, agricultural landscapes in Europe, but also in other parts of the world, have undergone major landscape transformations during the last 60 years (Baessler and Klotz, 2006; Stoate et al., 2001). Natural habitats disappeared when remnants of forests or wetlands were converted to agricultural land, while increasing field sizes caused the disappearance of many anthropogenic landscape elements such as hedgerows or field margins (e.g., Mix et al., 2006). These changes have seriously contributed to biodiversity loss and ultimately to the extinction of species within present-day cultural landscapes through habitat loss and habitat fragmentation (e.g., HietalaKoivu et al., 2004). Furthermore, in agricultural landscapes compositional changes result in an ongoing shift in species distributional patterns, with expansion of widespread generalist species and decrease of rare specialist species (Van der Veken et al., 2004).

Before becoming visible at the species level, the transformation of historic landscapes may affect the genetic makeup of populations, levels of gene flow, and the resulting population genetic structure (Manel et al., 2003; Young et al., 1996). Structural changes in agricultural landscapes such as the proportion, size or spatial arrangement of suitable habitat patches will change the interactions among neighbouring populations through changing gene flow patterns (Andren, 1994; Gustafson, 1998). Therefore, knowledge of landscape properties is important for a proper understanding of the genetic processes that generate spatial genetic structure (Manel et al., 2003; Sork et al., 1999).

In order to reveal the effects of landscape structure on genetic population structure of a common species, we selected Wood Avens (Geum urbanum L.) as study species. Due to its preference for a range of shaded edgehabitats, the species is a representative of semi-natural vegetation in agricultural landscapes. Hence, we consider it a suitable model to examine the consequences of landscape configuration on spatial genetic structure at small spatial scales. Because G. urbanum is highly selfing and because its populations are separated by mostly unsuitable habitat such as grasslands or agricultural fields, we expected that genetic differentiation among populations should increase with fragmentation. Genetic exchange among populations of selfing species such as G. urbanum relies primarily on seed dispersal, which is expected to be reduced due to habitat isolation and fragmentation. The landscape genetics of G. urbanum has recently been investigated in a single landscape in which case habitat connectivity was found to be a main factor determining genetic variation in small, but not in large populations (Vandepitte et al., 2007). Furthermore, recently colonized secondary forest populations were not more differentiated than those from primary patches, indicating a certain level of gene flow which, however, could not counteract the effect of genetic drift.

In this study the genetic variation of $G$. urbanum in three different European landscapes with different amounts of semi-natural habitats was quantified using microsatellite markers. We address the following questions: (1) Does population differentiation increase with the degree of habitat fragmentation among landscapes in a widespread selfing species such as G. urbanum? (2) Which landscape variables and specific landscape elements do affect genetic differentiation among populations? and (3) Are the relationships between genetic variability and landscape elements scale-dependent?

\section{Materials and methods}

\section{Species}

Geum urbanum L. (Wood Avens; Rosaceae) is a hexaploid $(2 n=6 x=42)$, perennial herb. It has a height of approximately $60 \mathrm{~cm}$ and an erect, slightly branched stem. The species has a pan-European distribution, which extends from the Ural Mountains and the southern Caucasus in the east to the Iberian Peninsula and the British Islands in the west (Hegi, 1975; Taylor, 1997). G. urbanum naturally occurs in shaded habitats within forests and along forest edges, hedgerows, scrub patches and orchards (Endels et al., 2004). The species propagates by seed. It has protogynous self-compatible yellow flowers that are pollinated mostly autogamously and only rarely by insects (Knuth, 1898; Taylor, 1997). 

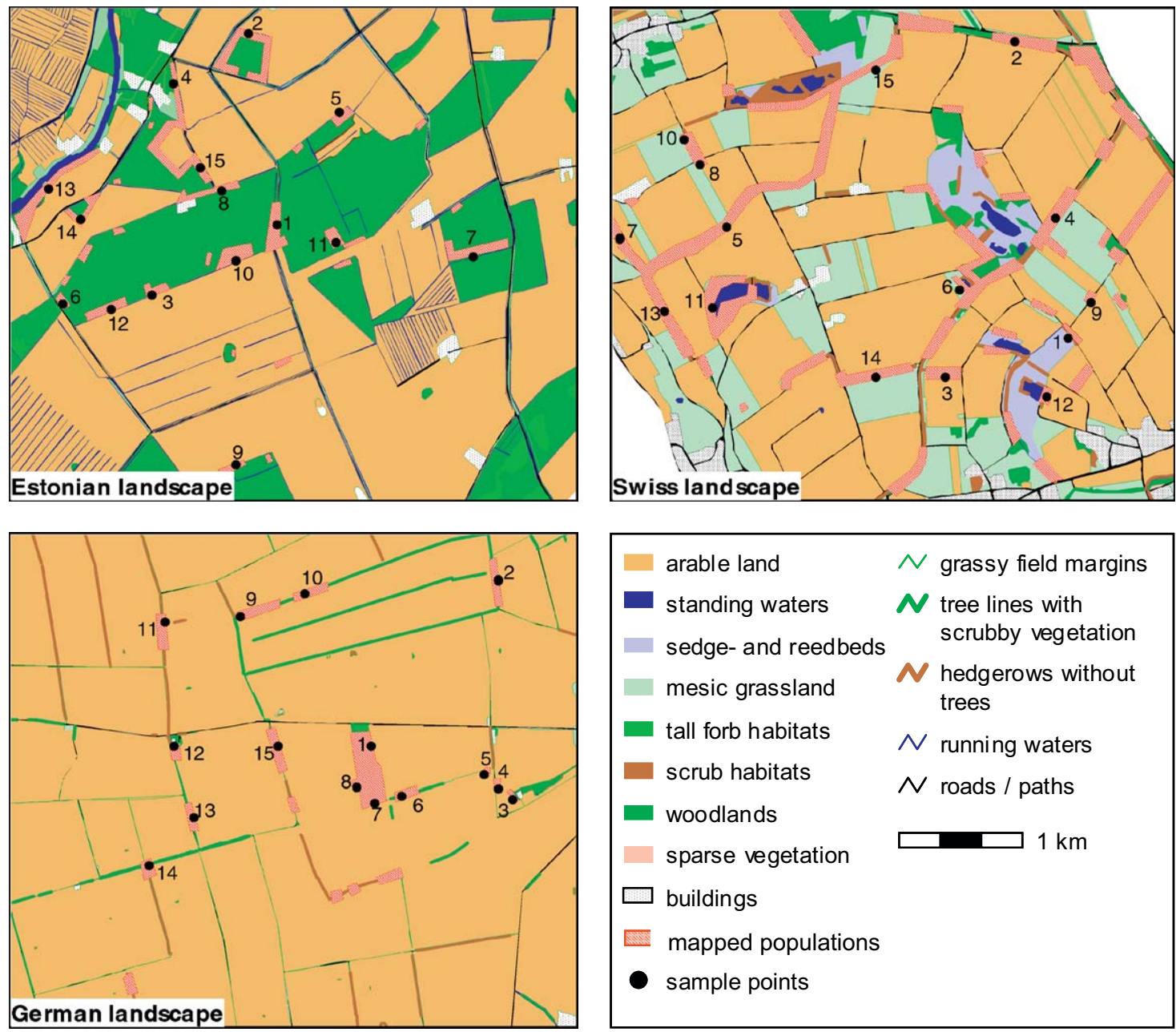

Fig. 1. Maps of landscape structure, Geum urbanum distribution and sample sites in Estonia, Switzerland and Germany. The distribution of $G$. urbanum along linear elements is enlarged to ensure visibility.

Seeds of G. urbanum are hairy and hooked, adapted to adhesive dispersal (Kiviniemi, 1996; Römermann et al., 2005). Although rather high germination rates were reported by Taylor (1997), the successful establishment of $G$. urbanum may be limited due to low survival rates at the seedling stage (Endels et al., 2004).

\section{Study sites and sampling design}

The analysis was carried out in three European agricultural landscapes of $4 \times 4 \mathrm{~km}^{2}$ (Fig. 1, Table 1). The three landscapes represent typical stages of the increasing fragmentation, e.g. degradation or loss of semi-natural habitat and coincided with field sites of the EU-project "Greenveins" (Billeter et al., 2008): a relatively slightly fragmented landscape in Estonia $\left(\mathrm{E}-\mathrm{VIH}, 58.57^{\circ} \mathrm{N}, 25.01^{\circ} \mathrm{E} ; 28 \%\right.$ wooded area, $56 \%$ agriculturally managed area; mean connectivity of G. urbanum populations: 3.55), a moderately fragmented landscape in Switzerland (H-REE, $42.27^{\circ} \mathrm{N}, 8.38^{\circ} \mathrm{E} ; 8 \%$ and $47 \%$, respectively; mean connectivity 2.23 ), and a severely fragmented landscape in Germany (G-QFP, $51.38^{\circ} \mathrm{N}, 11.72^{\circ} \mathrm{E} ; 1 \%$ and $96 \%$, respectively; mean connectivity 1.49 ).

Within each landscape all G. urbanum populations were mapped. Based on these surveys, within each landscape 15 populations were chosen haphazardly. In each population, young leaves were collected from 16 plants at random or from all individuals, if populations were smaller (Table 2). Efforts were made to avoid doublesampling of the same individual. Additionally, population size was estimated for each sampled population.

\section{Genotyping and genetic data analysis}

For genetic analyses, DNA was extracted from silica gel dried leaf tissue using the DNeasy plant mini kit (QIAGEN). A total of 826 samples were genotyped at 10 microsatellite loci with codominant, disomic behaviour following the protocol of Arens et al. (2004). 
Table 1. Metrics of land use, habitat area and landscape structure in the studied landscapes.

\begin{tabular}{|c|c|c|c|}
\hline Landscape variable & Estonia & Switzerland & Germany \\
\hline Arable land (\%) & 54.7 & 46.7 & 96.3 \\
\hline Total unmanaged area $(\%)$ & 35.9 & 41.6 & 2.7 \\
\hline Grasslands (\%) & 1.2 & 23.3 & 0.1 \\
\hline Woodland fringes/tall forb habitats $(\%)$ & 1.9 & 0.2 & 0.3 \\
\hline Field margins $(\%)$ & 0.4 & 1.4 & 0.8 \\
\hline Road verges $(\%)$ & 0.8 & 3.4 & 0.2 \\
\hline Margins of running waters $(\%)$ & 3.5 & 0.5 & 0.01 \\
\hline Area of shaded patches $(\%)$ & 28.4 & 8.3 & 1.5 \\
\hline Woodlands $(\%)$ & 22.3 & 5.3 & 0.5 \\
\hline Scrub habitats $(\%)$ & 0.1 & 0.9 & 0.1 \\
\hline Lines of trees $(\%)$ & 0.1 & 0.2 & 0.2 \\
\hline Hedgerows $(\%)$ & 0.7 & 0.5 & 0.1 \\
\hline Lines of scrubs $(\%)$ & 0.8 & 0.9 & 0.01 \\
\hline Landscape diversity & 0.43 & 0.60 & 0.29 \\
\hline Connectivity & 3.6 & 2.2 & 1.5 \\
\hline
\end{tabular}

Because some rare land-use types are not displayed, they do not sum to $100 \%$.

We estimated genetic variability within populations by the mean numbers of alleles $(A)$, observed $\left(H_{\mathrm{o}}\right)$ and expected $\left(H_{\mathrm{e}}\right)$ heterozygosity with MSA 3.0 (Dieringer and Schlötterer, 2003). Because mean number of alleles per locus is sensitive to sample size, allelic richness $\left(A_{r}\right)$, a measure independent of sample size, was calculated based on the minimum number of samples per population, $n=4$, using FSTAT 2.9.3 (Goudet, 2001). At the landscape level, the average values of these estimators were calculated across populations and compared by one-way ANOVA and by Tukey's HSD test.

Tests of deviations from Hardy-Weinberg expectations were calculated with GENEPOP 3.2 (Raymond and Rousset, 1995), with exact $p$-values determined by a Markov chain method. Unbiased estimates of Wright $F$-statistics (Weir and Cockerham, 1984) were obtained under the infinite allele model using FSTAT 2.9.3 (Goudet, 2001). Within each landscape, we estimated $\theta$, an estimator of Wright's $F_{\mathrm{ST}}$, over all populations and for all pairwise population comparisons, and the withinpopulation inbreeding coefficient $\left(F_{\text {IS }}\right)$. In order to obtain for each population a measure of genetic differentiation, pairwise $F_{\mathrm{ST}}$-values were averaged over all pairwise comparisons for each population. Significance of $F_{\mathrm{ST}^{-}}$and $F_{\mathrm{IS}}$-values was tested by bootstrapping over loci. Significance of multilocus pairwise

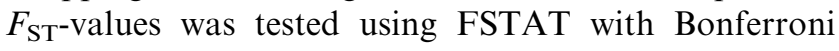
corrections.

To determine the partitioning of genetic variation, an analysis of molecular variance (AMOVA; Excoffier et al., 1992) was conducted with landscapes and populations as hierarchical levels using ARLEQUIN
(Schneider et al., 2000) with 1000 bootstrap replications. To assess whether genetic differentiation followed an isolation-by-distance model, the correlation between pairwise genetic distance $\left(F_{\mathrm{ST}}\right)$ and the logarithm of the pairwise geographic distance was analysed within each landscape with a Mantel test (Bohonak, 2002; Rousset, 1997).

Spatial genetic structure was further analysed by employing correlograms of Moran's I spatial autocorrelation statistics using SPAGEDI (Hardy and Vekemans, 1999), which assesses the correlation between the genetic similarity of individuals in relation to geographical distance (Schweiger et al., 2004). The number of distance classes was determined following Sturge's rule (Legendre and Legendre, 1998). The mean distance per distance class was used to draw correlograms. Significance of individual Moran's I-values was assessed by a resampling procedure (1000 permutations) and subsequent sequential Bonferroni correction. The range of genetic autocorrelation was estimated by the first $\mathrm{x}$-intercept of the Moran's I function (Escudero et al., 2003).

\section{Variables of landscape structure and multivariate data analysis}

For the analysis of landscape structure we digitized land use types from aerial photographs using ARCVIEW (ESRI 1996). We defined two circular areas around each $G$. urbanum population based on the minimum and maximum levels of spatial autocorrelation (100 and $400 \mathrm{~m}$; Fig. 2). Within these two circular 
Table 2. Population size, sample size $(n)$, mean number of alleles averaged over loci $(A)$, allelic richness $\left(A_{r}\right.$, based on $\left.n=4\right)$, observed heterozygosity $\left(H_{\mathrm{o}}\right)$ and expected heterozygosity $\left(H_{\mathrm{e}}\right)$ per population.

\begin{tabular}{|c|c|c|c|c|c|c|}
\hline & Population size & $n$ & $A$ & $\mathrm{~A}_{r}$ & $H_{\mathrm{o}}$ & $H_{\mathrm{e}}$ \\
\hline \multicolumn{7}{|l|}{ Estonia } \\
\hline Pop 1 & 40 & 16 & 2.1 & 1.4 & 0.006 & 0.26 \\
\hline Pop 2 & 400 & 16 & 1.7 & 1.4 & 0.006 & 0.12 \\
\hline Pop 3 & 12 & 12 & 1.4 & 1.4 & 0 & 0.17 \\
\hline Pop 4 & 500 & 16 & 1.5 & 1.5 & 0.02 & 0.13 \\
\hline Pop 5 & 50 & 16 & 1.7 & 1.2 & 0.03 & 0.17 \\
\hline Pop 6 & 10 & 16 & 1.2 & 1.9 & 0.01 & 0.05 \\
\hline Pop 7 & 250 & 16 & 2 & 1.3 & 0 & 0.35 \\
\hline Pop 8 & 150 & 16 & 1.5 & 1.7 & 0.02 & 0.09 \\
\hline Pop 9 & 15 & 16 & 1.8 & 1.2 & 0.01 & 0.3 \\
\hline Pop 10 & 26 & 15 & 1.2 & 1.3 & 0 & 0.07 \\
\hline Pop 11 & 20 & 16 & 1.5 & 1.6 & 0.01 & 0.1 \\
\hline Pop 12 & 35 & 16 & 1.8 & 1 & 0 & 0.23 \\
\hline Pop 13 & 3000 & 16 & 1.1 & 1.9 & 0.01 & 0.01 \\
\hline Pop 14 & 100 & 16 & 2.1 & 1.1 & 0.02 & 0.26 \\
\hline Pop 15 & 150 & 16 & 1.2 & 1.9 & 0 & 0.03 \\
\hline Mean & & 15.6 & 1.59 & 1.45 & 0.01 & 0.16 \\
\hline SE & & 1.1 & 0.33 & 0.29 & 0.009 & 0.104 \\
\hline \multicolumn{7}{|c|}{ Switzerland } \\
\hline Pop 1 & 40 & 16 & 2.6 & 1.8 & 0.03 & 0.43 \\
\hline Pop 2 & 3500 & 16 & 2.1 & 2.1 & 0.02 & 0.35 \\
\hline Pop 3 & 1500 & 16 & 2.6 & 1.6 & 0.05 & 0.31 \\
\hline Pop 4 & 350 & 16 & 1.6 & 1.7 & 0 & 0.18 \\
\hline Pop 5 & 800 & 16 & 2 & 1.8 & 0.01 & 0.27 \\
\hline Pop 6 & 50 & 16 & 2.3 & 1.5 & 0.03 & 0.33 \\
\hline Pop 7 & 1500 & 16 & 1.8 & 1 & 0 & 0.1 \\
\hline Pop 8 & 600 & 16 & 1.1 & 1.2 & 0.006 & 0.01 \\
\hline Pop 9 & 100 & 12 & 1.4 & 2.1 & 0 & 0.05 \\
\hline Pop 10 & 10 & 4 & 2.1 & 1.7 & 0 & 0.5 \\
\hline Pop 11 & 50 & 16 & 2.1 & 1.9 & 0.03 & 0.29 \\
\hline Pop 12 & 20 & 13 & 2.3 & 1.6 & 0.01 & 0.29 \\
\hline Pop 13 & 800 & 16 & 2.1 & 2.2 & 0.02 & 0.21 \\
\hline Pop 14 & 40 & 16 & 2.7 & 1.7 & 0.05 & 0.38 \\
\hline Pop 15 & 500 & 16 & 1.9 & 2.5 & 0.02 & 0.26 \\
\hline Mean & & 14.7 & 2.05 & 1.76 & 0.02 & 0.26 \\
\hline SE & & 3.2 & 0.44 & 0.38 & 0.017 & 0.136 \\
\hline \multicolumn{7}{|l|}{ Germany } \\
\hline Pop 1 & 500 & 16 & 2.3 & 1.5 & 0.07 & 0.44 \\
\hline Pop 2 & 50 & 16 & 2.5 & 2.3 & 0 & 0.36 \\
\hline Pop 3 & 150 & 10 & 1.8 & 2.1 & 0 & 0.17 \\
\hline Pop 4 & 500 & 16 & 2.6 & 2.1 & 0.04 & 0.2 \\
\hline Pop 5 & 2000 & 16 & 2.5 & 2.3 & 0.002 & 0.22 \\
\hline Pop 6 & 100 & 16 & 2.3 & 2.2 & 0.04 & 0.33 \\
\hline Pop 7 & 100 & 16 & 2.4 & 2.6 & 0.17 & 0.49 \\
\hline Pop 8 & 10 & 16 & 2.3 & 2 & 0.09 & 0.41 \\
\hline Pop 9 & 20 & 16 & 2.9 & 1 & 0.03 & 0.44 \\
\hline Pop 10 & 15 & 14 & 2.3 & 1.3 & 0.09 & 0.45 \\
\hline Pop 11 & 10 & 6 & 1 & 1.6 & 0.04 & 0.48 \\
\hline Pop 12 & 50 & 16 & 1.5 & 1 & 0.06 & 0.28 \\
\hline Pop 13 & 50 & 16 & 2 & 2 & 0 & 0 \\
\hline Pop 14 & 20 & 16 & 1 & 2.4 & 0.01 & 0.07 \\
\hline Pop 15 & 150 & 16 & 1.3 & 3 & 0.02 & 0.18 \\
\hline Mean & & 14.8 & 2.05 & 1.96 & 0.04 & 0.27 \\
\hline SE & & 2.9 & 0.59 & 0.58 & 0.047 & 0.155 \\
\hline
\end{tabular}



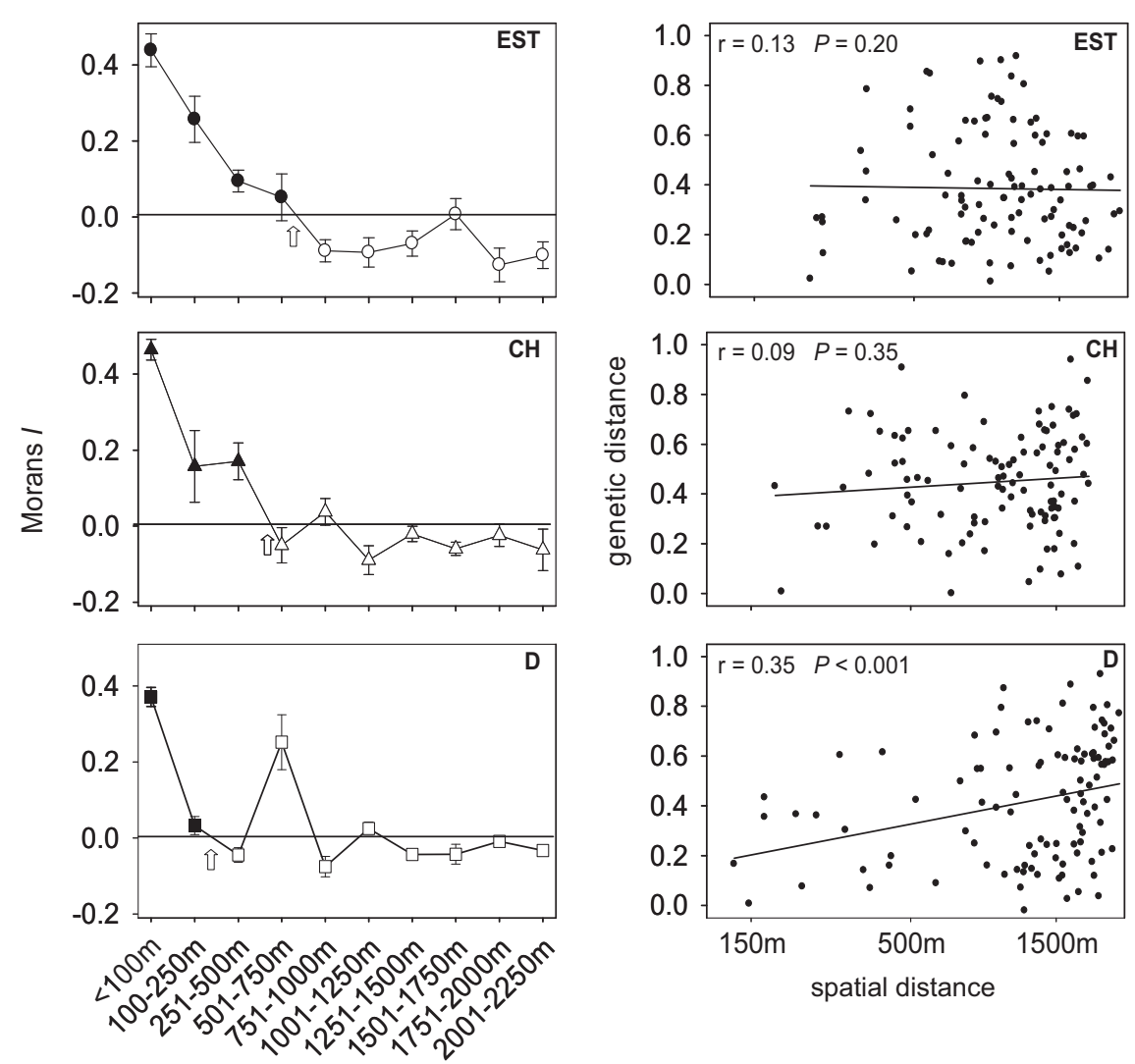

Fig. 2. Spatial genetic structure of G. urbanum. Left panel: autocorrelograms based on individual pairwise Moran's $I$ coefficients. Full symbols indicate significant autocorrelation coefficients. Error bars indicate $95 \%$ confidence intervals of Moran's $I$ coefficients. Arrows indicate the range of spatial genetic autocorrelation. Right panel: relationships between genetic distance $\left(F_{\mathrm{ST}}\right)$ and geographic distance (Mantel test). Capitals refer to landscapes EST - Estonia, CH - Switzerland, D - Germany.

areas, local landscape structure was quantified by landscape metrics calculated with FRAGSTATS (McGarigal and Marks, 1994): (1) landscape diversity (Shannon diversity of land use types), (2) amount of shaded habitat area, representing the potential habitat of G. urbanum and (3) percentage share of all land use types present. To avoid too many zero values in the explanatory variables, we excluded those land use types that were recorded in less than $80 \%$ of the circular areas. Note that therefore the number of variables varied between the analyses depending on the number of land use types enclosed among landscapes and circle radii (8-10 land use types for the $100 \mathrm{~m}$ and $12-16$ land use types for the $400 \mathrm{~m}$ radius). The set of explanatory variables included further (4) connectivity of Geum populations, and (5) spatial position. Connectivity of each G. urbanum population to all other populations within the focal landscapes was calculated according to $S_{i}=\sum \exp \left(-d_{i j}\right) A_{j}$, where $d_{i j}$ is the spatial distance between sites $i$ and $j$ and $A_{j}$ is the area of site $j$. This formula corresponds to Hanski's (1994) connectivity index with $\alpha$, the scaling factor accounting for mortality during migration, set to unity (Moilanen and Nieminen, 2002). Spatial position (centred geographical coordi- nates LAT, LONG) of each population was included to possibly account for pure arrangement effects.

Generalized linear modelling (GLM) was used to quantify the contributions of landscape diversity, landscape structural elements, connectivity and spatial position to genetic diversity of $G$. urbanum populations. In total we created 18 statistical models, relating for each of the three landscapes, the three measures of genetic variation, allelic richness $\left(A_{r}\right)$, observed heterozygosity $\left(H_{\mathrm{e}}\right)$ and population differentiation $\left(F_{\mathrm{ST}}\right)$ as dependent variables to the independent variables, calculated for two circular areas. The procedure of model formulation followed Vandepitte et al. (2007). Statistical calculations were performed with the software package R, version 2.1.0 (www.r-project.org).

\section{Results}

\section{Genetic variation within populations}

A total of 73 alleles were detected in 10 microsatellite loci across the three studied landscapes. The highest number of alleles was found in the Swiss populations 
(58 alleles), followed by the German and Estonian populations with 50 and 43 alleles, respectively. The mean number of alleles per locus was 7.4 (range: 2 at locus WGU1-33 to 16 at locus WGU6-7), and an average of 5.6 alleles was observed per locus per population. In total 24 of the 73 alleles recorded $(\approx 32 \%)$ were private alleles restricted to a single study site (11 in Switzerland, 8 in Germany and 5 in Estonia).

Values of genetic diversity at population and landscape level are given in Table 2. Among the three landscapes, the populations from Estonia showed a significantly lower level of genetic diversity than the populations from Germany and Switzerland with respect to average number of alleles per locus (ANOVA: $\left.F_{2 / 42}=4.80 ; p=0.013\right)$, allelic richness $\left(F_{2 / 42}=5.22\right.$; $p=0.009), \quad$ expected heterozygosity $\quad\left(F_{2 / 42}=8.96\right.$; $p=0.004)$ and observed heterozygosity $\left(F_{2 / 42}=10.59\right.$; $p=0.002)$. In all three landscapes, population size was not correlated with expected heterozygosity $(p>0.15)$.

Of the 45 populations tested for conformity to Hardy-Weinberg equilibrium, 41 showed a significant departure due to an excess of homozygotes. The mean inbreeding coefficient over all loci and populations was high $(F=0.89 \pm 0.04$; mean $\pm \mathrm{SD})$ and was not significantly different among the three landscapes. Based on this inbreeding coefficient and assuming inbreeding equilibrium, the mean selfing rate across all populations was $s=0.92 \pm 0.16$ (Nei and Syakundo, 1958), indicating predominant self-fertilization in G. urbanum.

\section{Population differentiation}

Overall, populations were highly structured as revealed by an analysis of molecular variance (AMOVA). Approximately $31 \%$ and $33 \%$ of the total genetic variation was found among landscapes and among populations within landscapes (Table 3 ), the remaining variance $(36 \%)$ was retained within populations. Among all populations a remarkably high level of differentiation was found $(\theta=0.61,95 \% \mathrm{CI}=0.607-$ $0.619, p<0.001)$. Significant differentiation was detected for more than $90 \%$ of the 105 possible pairwise combinations of populations within each landscape. At the landscape level overall $F_{\mathrm{ST}}$-estimates were $\theta=0.43$ (95\% CI: $0.33-0.49)$ for Estonia, $\theta=0.48(0.46-0.49)$ for Switzerland and $\theta=0.45(0.44-0.47)$ for Germany and did not differ among landscapes. Hence, at the landscape level no effect of landscape structure on population differentiation was detectable. In addition, average $F_{\mathrm{ST}}$-estimates per population were not correlated to population size $(p>0.3)$.

No significant correlation between pairwise genetic $\left(F_{\mathrm{ST}}\right)$ and spatial distances among pairs of populations was detected in the two less fragmented landscapes in Estonia and Switzerland (Fig. 2). However, in the intensively fragmented German site significant isolation by distance was found $(r=0.37, p=0.01)$. A significant pattern of spatial genetic structure was revealed by spatial autocorrelation analysis within each landscape (Fig. 2), indicating a range of genetic influence up to approximately 100, 200 and $400 \mathrm{~m}$ for the German, Swiss and Estonian landscape, respectively.

\section{Genetic diversity and landscape structure}

Overall, GLMs revealed only a moderate influence of landscape structure on the distribution of genetic variation, since only 9 significant models were obtained from 18 analyses (Table 4). The three landscapes differed in the genetic variables that were correlated to landscape structure. Whereas genetic differentiation among populations $\left(F_{\mathrm{ST}}\right)$ was best explained in the German landscape (up to $57 \%$ explained variance); the explained variance of allelic richness $\left(A_{r}\right)$ as well as of expected heterozygosity $\left(H_{\mathrm{e}}\right)$ was highest in the Swiss landscape with values of greater than $54 \%$.

In the slightly fragmented Estonian landscape a positive influence of the occurrence of grassy field margins on allelic richness $\left(A_{r}\right)$ emerged at the $100 \mathrm{~m}$ scale, while at the $400 \mathrm{~m}$ scale allelic richness was favoured by the percentage share of hedgerows. However, $H_{\mathrm{e}}$ was negatively influenced by grassy field margins and by increasing connectivity at the $100 \mathrm{~m}$ scale. Genetic variation among populations $\left(F_{\mathrm{ST}}\right)$ was not related to landscape variables.

Table 3. Hierarchical analysis of molecular variance (AMOVA) across three studied landscapes, each with 15 G. urbanum populations.

\begin{tabular}{lrrrr}
\hline Source of variation & d.f. & Sum of squares & Variance components & $\%$ of total variance \\
\hline Among landscapes & 2 & 984.14 & 0.836 & $29.7^{* * *}$ \\
Among populations within landscapes & 42 & 1450.62 & 0.913 & $32.5^{* * *}$ \\
Within populations & 1602 & 1704.15 & 1.064 & $37.8^{* * *}$ \\
& & & & 2.813 \\
Total & 1649 & 4138.91 &
\end{tabular}

\footnotetext{
$* * * p<0.001$.
} 
Table 4. Summary statistics for multiple regression analyses in three landscapes for measures of genetic diversity within $\left(A_{\mathrm{r}}, H_{\mathrm{e}}\right)$ and among-populations $\left(F_{\mathrm{ST}}\right)$ as dependent on variables of landscape structure in two circle diameters.

\begin{tabular}{|c|c|c|c|c|c|c|}
\hline \multirow[b]{2}{*}{ Landscape } & \multicolumn{3}{|l|}{$100 \mathrm{~m}$ circles } & \multicolumn{3}{|l|}{$400 \mathrm{~m}$ circles } \\
\hline & Variable & $t$-Value & $\begin{array}{l}\text { Percentage expl. } \\
\text { variance }(p)\end{array}$ & Variable & $t$-Value & $\begin{array}{l}\text { Percentage expl. } \\
\text { variance }(p)\end{array}$ \\
\hline \multicolumn{7}{|l|}{ Estonia } \\
\hline$A_{\mathrm{r}}$ & Grassy margins & 2.29 & $23.3(0.039)$ & Hedgerow & 2.47 & $26.8(0.028)$ \\
\hline$H_{\mathrm{e}}$ & $\begin{array}{l}\text { Grassy margins } \\
\text { Connectivity }\end{array}$ & $\begin{array}{l}-2.55 \\
-2.67\end{array}$ & $41.6(0.016)$ & - & & (n.s.) \\
\hline$F_{\mathrm{ST}}$ & - & & (n.s.) & - & & (n.s.) \\
\hline \multicolumn{7}{|l|}{ Switzerland } \\
\hline$A_{\mathrm{r}}$ & - & & (n.s.) & $\begin{array}{l}\text { Orchards } \\
\text { Hedgerow }\end{array}$ & $\begin{array}{l}-3.15 \\
-2.19\end{array}$ & $32.4(0.038)$ \\
\hline$H_{\mathrm{e}}$ & $\begin{array}{l}\text { Grassland } \\
\text { Grassland x grassy margin }\end{array}$ & $\begin{array}{l}-4.15 \\
-3.29\end{array}$ & $54.3(0.003)$ & - & & (n.s.) \\
\hline$F_{\mathrm{ST}}$ & - & & (n.s.) & - & & (n.s.) \\
\hline \multicolumn{7}{|l|}{ Germany } \\
\hline$A_{\mathrm{r}}$ & $\begin{array}{l}\text { Grassland } \\
\text { Open tree lines }\end{array}$ & $\begin{array}{l}-2.22 \\
-1.96\end{array}$ & $29.6(0.048)$ & - & & (n.s.) \\
\hline$H_{\mathrm{e}}$ & - & & (n.s.) & $\begin{array}{l}\text { Woodland } \\
\text { Reforestation }\end{array}$ & $\begin{array}{r}-2.91 \\
2.12\end{array}$ & $32.4(0.037)$ \\
\hline$F_{\mathrm{ST}}$ & Connectivity & -2.53 & $27.9(0.025)$ & $\begin{array}{l}\text { Scrub } \\
\text { Latitude }\end{array}$ & $\begin{array}{l}-3.68 \\
-2.22\end{array}$ & $57.3(0.002)$ \\
\hline
\end{tabular}

Significant variables, $t$-values, explained variance $(\%)$ and $p$-values in parentheses are given.

In the moderately fragmented landscape in Switzerland, allelic richness $\left(A_{r}\right)$ showed strong negative relationships to the proportion of hedgerows and orchards $(400 \mathrm{~m})$. These variables explained approximately $59 \%(400 \mathrm{~m})$ of the variance in $A_{r}$. At a scale of $100 \mathrm{~m}$ the proportion of grassland had a negative effect on expected heterozygosity $\left(H_{\mathrm{e}}\right)$ and explained approximately $54 \%$ of the variance. Differences in population differentiation $\left(F_{\mathrm{ST}}\right)$ could neither be explained by the landscape variables.

In the severely fragmented German landscape, allelic richness decreased with increasing proportion of grassland patches and open tree lines at the $100 \mathrm{~m}$ scale, accounting for $29 \%$ of the variance. Expected heterozygosity $\left(H_{\mathrm{e}}\right)$ was negatively correlated to the proportion of woodlands but showed a positive correlation to recent reforestations, explaining $32 \%$ of the variance at $400 \mathrm{~m}$. The degree of differentiation among populations $\left(F_{\mathrm{ST}}\right)$ decreased with an increasing connectivity $(100 \mathrm{~m}$ scale; $28 \%$ explained variance), and with increasing proportion of scrub $(400 \mathrm{~m}$ scale; $57 \%)$. Additionally, for $F_{\mathrm{ST}}$ a significant latitudinal gradient (LAT) was detected indicating a cline for $F_{\mathrm{ST}}$ across the landscape.

\section{Discussion}

The main objective of this study was to evaluate the impact of the contemporary landscape structure on the population genetic structure of G. urbanum, a species widespread in European agricultural landscapes. The results showed that: (i) populations of all three landscapes exhibited substantial genetic variation and pronounced genetic differentiation; (ii) genetic variation was equally divided among individuals within populations, among populations within landscapes and among landscapes; (iii) the abundance of certain landscape features was of importance for the distribution of genetic variation within and among $G$. urbanum populations, depending on the degree of landscape fragmentation and the spatial scale considered. We argue that the patterns of genetic variation might be best explained by the combined effect of three factors: (1) the biology of the species, in particular the mating system, (2) long-lasting changes in the structure of the landscape resulting in discontinuous habitat, and (3) the background genetic variation at biogeographical scales as a result of postglacial colonisation.

\section{Effects of the mating system}

Almost all sampled populations showed a large heterozygote deficit typical for highly selfing species. Inbreeding coefficients were not affected by population size and did not differ among landscapes, indicating 
similarly high selfing rates. Compared to outcrossing species, the selfing behaviour of $G$. urbanum makes it independent from pollinating insects. Thus, the high selfing rate may enable the species to persist even under frequent anthropogenic disturbance and increasing landscape fragmentation. Despite of the substantial degree of inbreeding, G. urbanum populations maintain relatively high values of within-population diversity which shows that multiple genotypes persist locally. Furthermore, the estimated equilibrium outcrossing rate of $8 \%$ and the observed heterozygous genotypes ( $8 \%$ of all multilocus genotypes) are consistent with some outbreeding, contributing to the maintenance of genetic variation at population level (Green et al., 2001).

\section{Effects of landscape structure on genetic differentiation among populations}

G. urbanum showed a pronounced genetic differentiation among populations in the three agricultural landscapes. Such patterns have been frequently reported as an effect of self-fertilization (Barrett and Kohn, 1991; Berge et al., 1998; Durka et al., 2005). However, selffertilizing species are not necessarily strongly differentiated at the landscape scale, when gene flow is maintained, as has been shown for Anthyllis vulneraria (Honnay et al., 2006). However, differentiation among G. urbanum populations was neither related to population size, nor, except for the German landscape, to the geographic distance among populations. Overall, the lack of a clear effect on differentiation in relation to geographic distance indicates a dominant role of genetic drift relative to gene flow (Hutchison and Templeton, 1999). For the German landscape, the weak isolation by distance pattern found (Fig. 2) is mirrored by an effect of connectivity in the multivariate analyses. This suggests some gene flow across short distances, however, without large effect on the overall differentiation which did not differ between landscapes.

Landscape configuration has also been suggested to make a considerable contribution to the genetic differentiation among populations (Prentice et al., 2006). This was confirmed by the negative influence of hostile landscape elements like grassland for both within population diversity and population differentiation. Notably, landscape diversity per se was not relevant for the genetic variation and gene flow among populations, rather the presence of potential habitat patches played a role. However, different variables of landscape structure accounted for genetic variation in the three landscapes. Moreover, the negative correlation between woodlands and hedgerows and genetic variation which appeared in the German and Swiss landscape was unexpected. However, from a historical perspective, particularly the German landscape was almost devoid of woodlands and hedgerows during the first half of the 20 th century. Only in the 1950 s shelterbelts and patchy forests were established followed by hedgerows planted in the 1980s. Thus, woodlands and hedgerows represent very young habitats and, therefore, have only recently been colonized. Founder events during colonisation may still dominate the genetic patterns and lead to low levels of genetic diversity in these hedgerows. As has been shown for other species, patch age or habitat continuity may therefore be a major determinant of current genetic patterns (Jacquemyn et al., 2004; Prentice et al., 2006).

Overall, for the three landscapes and three genetic variables, only nine significant, seemingly idiosyncratic, models could be found. Several non exclusive explanations may account for this result. First, landscape structure was represented by the proportion of various habitat types, complemented by a set of variables describing characteristic features of the patches inhabited by G. urbanum populations. Although Gustafson (1998, p. 150) has already argued that: “... knowing the proportion of a (Gustafson, 1998 [habitat]) type of interest tells you almost as much as knowing many other measures of heterogeneity", not only the proportion of individual habitat types but other factors may have influenced the observed patterns. Depending on the proportion of suitable habitat, either the amount of habitat or habitat isolation may be more important (Andren, 1994). Second, although all landscapes where mapped with a common standard, the land use types distinguished may vary in their suitability as habitat for G. urbanum within and among landscapes. For example, depending on the management, shrub species composition and spatial extent, hedgerows vary drastically in their herbal layer including G. urbaum as indicated by the variable association with hedgerows across the landscapes (Fig. 1). Also, the land use types distinguished may partly represent habitat of similar suitability but entered the analysis as different variables. Third, the genetic structure of plants in isolated habitats may be influenced by rare colonisation events and founder effects (Solé et al., 2004). The selfing breeding system of G. urbanum will tend to preserve the pattern of colonisation for relatively long periods of time, thus reducing the pace at which changes in landscape structure can affect the genetic structure of populations. Therefore, the inherent species traits may predetermine the stochastic rather than deterministic patterns. Fourth, $F_{\mathrm{ST}}$ does not reflect current gene flow and present-day landscape structure, but rather mirrors the sum of the historical conditions (Prentice et al., 2006; Whitlock and McCauley, 1999). Therefore, population genetic patterns may be blurred in the dynamic European cultural landscapes. Last, while some land use types may represent potential habitat of G. urbanum, gene flow via seed dispersal needs seed dispersers being large mammals or humans, the frequency of which may 
be not well represented by the landscape variables at hand.

We analysed the effect of spatial scale by including the populations surrounding to either a 100 or a $400 \mathrm{~m}$ distance to calculate the share of land use types. The two scales revealed a similar number of statistically significant models, however, in most cases only in one of the two scales. When both scales yielded significant models, different variables where identified. While this shows the importance of scale, no clear pattern emerges on the importance of either of the two scales with respect to the land use types. This again shows that while genetic autocorrelation was detected, it is difficult to identify the underlying drivers at the landscape level.

\section{Large-scale biogeographic patterns}

Genetic diversity in the Estonian populations was lower than in the German and Swiss populations. Estonia is at the northern periphery of the range of G. urbanum. Thus, postglacial colonisation history may provide an explanation for the large-scale pattern in genetic diversity. Postglacial range extension may have been accompanied by repeated genetic bottlenecks, leading to reduced genetic variation in the northern part of the species range. Similar south-north clines of genetic variation have been shown for other selfing herbaceous plant species (Chauvet et al., 2004; Durka, 1999). However, the level of population differentiation did not differ between the three landscapes, indicating that the underlying processes are similar across large parts of the species' range.

\section{Acknowledgements}

We thank M. Herrmann and I. Geyer (UFZ) for the technical help. This study was carried out with financial support from the Commission of the European Community, Energy, Environment and Sustainable Development Programme (Greenveins-Project, EVK2-CT2000-00082) and from the Netherlands' Ministry of Agriculture, Nature and Food Safety.

\section{References}

Andren, H., 1994. Effects of habitat fragmentation on birds and mammals in landscapes with different proportions of suitable habitat: a review. Oikos 71, 355-366.

Arens, P., Durka, W., Wernke-Lenting, J.W., Smulders, M.J.M., 2004. Isolation and characterization of microsatellite loci in Geum urbanum (Rosaceae) and their transferability within the genus Geum. Mol. Ecol. Notes 4, 209-212.

Baessler, C., Klotz, S., 2006. Effects of changes in agricultural land-use on landscape structure and arable weed vegetation over the last 50 years. Agricult. Ecosyst. Environ. 115, 43-50.

Barrett, S.C.H., Kohn, J.R., 1991. Genetic and evolutionary consequences of small population size in plants: implications for conservation. In: Falk, D.A., Holsinger, K.E. (Eds.), Genetics and Conservation of Rare Plants. Oxford University Press, Oxford, pp. 3-30.

Berge, G., Nordal, I., Hestmark, G., 1998. The effect of breeding systems and pollination vectors on the genetic variation of small plant populations within an agricultural landscape. Oikos 81, 17-29.

Billeter, R., Liira, J., Bailey, D., Bugter, R., Arens, P., Augenstein, I., Aviron, S., Baudry, J., et al., 2008. Indicators for biodiversity in agricultural landscapes: a pan-European study. J. App. Ecol. 45, 141-150.

Bohonak, A.J., 2002. IBD (isolation by distance): a program for analyses of isolation by distance. J. Hered. 93, 153-154.

Chauvet, S., van der Velde, M., Imbert, E., Guillemin, M.L., Mayol, M., Riba, M., Smulders, M.J.M., Vosman, B., Ericson, L., Bijlsma, R., Giles, B.E., 2004. Past and current gene flow in the selfing, wind-dispersed species Mycelis muralis in western Europe. Mol. Ecol. 13, 1391-1407.

Dieringer, D., Schlötterer, C., 2003. Microsatellite Analyser (MSA): a platform independent analysis tool for large microsatellite data sets. Mol. Ecol. Notes 3, 167-169.

Durka, W., 1999. Genetic diversity in peripheral and subcentral populations of Corrigiola litoralis L. (Illecebraceae). Heredity 83, 476-484.

Durka, W., Bossdorf, O., Prati, D., Auge, H., 2005. Molecular evidence for multiple introductions of invasive garlic mustard (Alliaria petiolata, Brassicaceae) to North America. Mol. Ecol. 14, 1697-1706.

Endels, P., Adriaens, D., Verheyen, K., Hermy, M., 2004. Population structure and adult plant performance of forest herbs in three contrasting habitats. Ecography 27, 225-241.

Escudero, A., Iriondo, J.M., Torres, M.E., 2003. Spatial analysis of genetic diversity as a tool for plant conservation. Biol. Conserv. 113, 351-365.

Excoffier, L., Smouse, P.E., Quattro, J.M., 1992. Analysis of molecular variance inferred from metric distances among DNA haplotypes: application to human mitochondrial DNA restriction sites. Genetics 131, 479-491.

Goudet, J., 2001. FSTAT, a program to estimate and test gene diversities and fixation indices (version 2.9.3). Available from 〈http://www.unil.ch/izea/softwares/fstat.html $\rangle$. Updated from Goudet (1995).

Green, J.M., Barker, J.H.A., Marshall, E.J.P., Froud-Williams, R.J., Peters, N.C.B., Arnold, G.M., Dawson, K., Karp, A., 2001. Microsatellite analysis of the inbreeding grass weed Barren Brome (Anisantha sterilis) reveals genetic diversity at the within- and between-farm scales. Mol. Ecol. 10, 1035-1045.

Gustafson, E.J., 1998. Quantifying landscape spatial pattern: what is the state of the art? Ecosystems 1, 143-156.

Hanski, I., 1994. A practical model of metapopulation dynamics. J. Anim. Ecol. 63, 51-63.

Hardy, O.J., Vekemans, X., 1999. Isolation by distance in a continuous population: reconciliation between spatial autocorrelation analysis and population genetics models. Heredity 83, 145-154. 
Hegi, G., 1975. Illustrierte Flora von Mitteleuropa, Vol. V. Paul Parey, Berlin, Hamburg.

Hietala-Koivu, R., Lankoski, J., Tarmi, S., 2004. Loss of biodiversity and its social cost in an agricultural landscape. Agricult. Ecosyst. Environ. 103, 75-83.

Honnay, O., Coart, E., Butaye, J., Adriaens, D., Van Glabeke, S., Roldan-Ruiz, I., 2006. Low impact of present and historical landscape configuration on the genetics of fragmented Anthyllis vulneraria populations. Biol. Conserv. 127, 411-419.

Hutchison, D.W., Templeton, A.R., 1999. Correlation of pairwise genetic and geographic distance measures: Inferring the relative influences of gene flow and drift on the distribution of genetic variability. Evolution 53, 1898-1914.

Jacquemyn, H., Honnay, O., Galbusera, P., Roldan-Ruiz, I., 2004. Genetic structure of the forest herb Primula elatior in a changing landscape. Mol. Ecol. 13, 211-219.

Kiviniemi, K., 1996. A study of adhesive seed dispersal of three species under natural conditions. Acta Bot. Neerl. 45, 73-83.

Knuth, P., 1898. Handbuch der Blüthenbiologie. Engelmann, Leipzig.

Legendre, P., Legendre, L., 1998. Numerical Ecology. Elsevier, Amsterdam.

Manel, S., Schwartz, M.K., Luikart, G., Taberlet, P., 2003. Landscape genetics: combining landscape ecology and population genetics. Trends Ecol. Evol. 18, 189-197.

Maurer, K., Weyand, A., Fischer, M., Stöcklin, J., 2006. Old cultural traditions, in addition to land use and topography, are shaping plant diversity of grasslands in the Alps. Biol. Conserv. 130, 438-446.

McGarigal, K., Marks, B., 1994. Fragstats - Spatial pattern analysis program for quantifying landscape structure. Forest Science Department, Oregon State University, Corvallis.

Mix, C., Arens, P.F.P., Rengelink, R., Smulders, M.J.M., van Groenendael, J.M., Ouborg, N.J., 2006. Regional gene flow and population structure of the wind-dispersed plant species Hypochaeris radicata (Asteraceae) in an agricultural landscape. Mol. Ecol. 15, 1749-1758.

Moilanen, A., Nieminen, M., 2002. Simple connectivity measures in spatial ecology. Ecology 83, 1131-1145.

Nei, M., Syakundo, M., 1958. The estimation of outcrossing in natural populations. Jpn. J. Genet. 33, 46-51.

Pimentel, D., Stachow, U., Takacs, D.A., Brubaker, H.W., Dumas, A.R., Meaney, J.J., Oneil, J.A., Onsi, D.E., Corzilius, D.B., 1992. Conserving biological diversity in agricultural forestry systems - most biological diversity exists in human-managed ecosystems. Bioscience 42, 354-362.
Prentice, H.C., Lönn, M., Rosquist, G., Ihse, M., Kindström, M., 2006. Gene diversity in a fragmented population of Briza media: grassland continuity in a landscape context. J. Ecol. 94, 87-97.

Raymond, M., Rousset, F., 1995. GENEPOP (version 1.2): a population genetics software for exact tests and ecumenicism. J. Hered. 86, 248-249.

Römermann, C., Tackenberg, O., Poschlod, P., 2005. How to predict attachment potential of seeds to sheep and cattle coat from simple morphological seed traits. Oikos 110, 219-230.

Rousset, F., 1997. Genetic differentiation and estimation of gene flow from $F$-statistics under isolation by distance. Genetics 145, 1219-1228.

Schneider, S., Roessli, D., Excoffier, L., 2000. ARLEQUIN ver 2.000: a software for population genetic data analysis. Genetics and Biometry Laboratory. University of Geneva, Geneva, Switzerland.

Schweiger, O., Frenzel, M., Durka, W., 2004. Spatial genetic and morphological structure in a metapopulation of the land snail Cepaea nemoralis (Gastropoda: Helicidae) in a fragmented landscape. Mol. Ecol. 13, 3645-3655.

Solé, M., Durka, W., Eber, S., Brandl, R., 2004. Genotypic and genetic diversity of the common weed Cirsium arvense (Asteraceae). Int. J. Plant Sci. 165, 437-444.

Sork, V.L., Nason, J., Campbell, D.R., Fernandez, J.F., 1999. Landscape approaches to historical and contemporary gene flow in plants. Trends Ecol. Evol. 14, 219-224.

Stoate, C., Boatman, N.D., Borralho, R.J., Carvalho, C.R., de Snoo, G.R., Eden, P., 2001. Ecological impacts of arable intensification in Europe. J. Environ. Manag. 63, 337-365.

Taylor, K., 1997. Biological Flora of the British Isles: Geum urbanum L. J. Ecol. 85, 705-720.

Van der Veken, S., Verheyen, K., Hermy, M., 2004. Plant species loss in an urban area (Turnhout, Belgium) from 1880 to 1999 and its environmental determinants. Flora 199, 516-523.

Vandepitte, K., Jacquemyn, H., Roldan-Ruiz, I., Honnay, O., 2007. Landscape genetics of the self-compatible forest herb Geum urbanum: effects of habitat age, fragmentation and local environment. Mol. Ecol. 16, 4171-4179.

Weir, B.S., Cockerham, C.C., 1984. Estimating $F$-statistics for the analysis of population structure. Evolution 38, 1358-1370.

Whitlock, M.C., McCauley, D.E., 1999. Indirect measures of gene flow and migration: $F_{\mathrm{ST}}$ not equal $1 /(4 \mathrm{Nm}+1)$. Heredity 82, 117-125.

Young, A., Boyle, T., Brown, T., 1996. The population genetic consequences of habitat fragmentation for plants. Trends Ecol. Evol. 11, 413-418. 